\title{
A Quarter Century of Economic Reforms of India (1991-2016)
}

\author{
Gouher Ahmed \\ Skyline University College, University City of Sharjah, UAE \\ Email: gouher@usa.net
}

How to cite this paper: Ahmed, G. (2017)

A Quarter Century of Economic Reforms of India (1991-2016). Theoretical Economics Letters, 7, 1102-1107.

https://doi.org/10.4236/tel.2017.75074

Received: May 18, 2017

Accepted: July 1, 2017

Published: July 4, 2017

Copyright $\odot 2017$ by author and Scientific Research Publishing Inc. This work is licensed under the Creative Commons Attribution International License (CC BY 4.0).

http://creativecommons.org/licenses/by/4.0/

\begin{abstract}
The paper is a critical review of India's progress of economic reforms (19912016). The relative failures of the past quarter century are considered, and the ways in which the reforms could be strengthened are suggested.

\section{Keywords}

Quarter Century of Economic Reforms, India, Colonial Development, Pre-Reforms Development, Post Reforms Development
\end{abstract}

\section{Introduction}

India, with a large population of 1.31 billion [1], an ancient and enduring civilization, rich culture, intellectual tradition, vast diversity, a growing economy and democratic polity, is a nation of global interest. It is an important leader of postcolonial economic development of the second part of the $20^{\text {th }}$ century with its USP of state planning after independence (1947) from two centuries of the British colonial rule, independence, however, was at the great cost of bifurcation of the country into India and Pakistan, the aftermath of which is bitter Indo-Pak relations and three wars between the two countries and the forever cold war like atmosphere between the two, which is undiplomatic and anti-developmental. Modern diplomacy is building bridges and good neighborliness.

On the whole, India's economic development is made up of colonialism to economic planning to economic reforms and free market economy, with some countries like the ASEAN ones and the young and dynamic UAE opting for the ultimate or the "golden" means of development of free enterprise.

\section{Colonial Development}

The colonial development of India cannot be considered much, as by definition and implication, colonialism is treating colonies or dependent or imperial terri- 
tories as the source of raw materials and markets for the imperial products. The fact of India (undivided) being the largest of colonial territory ever known to history would not have made any significant difference to the British colonial theory. It is significant that England was the swing of the Industrial revolution (1760-1830) the rumblings which could not have been avoided in India. It was in the interest of England to promote English education, colleges and universities, railways, post offices, public works, law courts, administrative services, military, police services, irrigation works, plantation industries, and so on to make the country going and maintain law and order and public peace. There were banks and agricultural credit cooperative societies.

The Indian industrialists on their own, fired by the spirit of nationalism or swadeshi, had added plantation, iron-steel, textile, jute, cement, paper, pharmaceutical. And, the vast agricultural sector, the backbone of the Indian economy, was characterized by rent farming, a typical British innovation, with a poor peasantry in debt and economic distress.

In sum, the time of independence, the Indian economy was a small one of about Rs. 10,000 crores or $\$ 1.56$ billion and foreign trade of about Rs. 1000 crore or $\$ 156.25 \mathrm{mln}$, (Rupees $64=\$ 1$ ) but with the a Malthusian population of 360 million with a per capita income of less than 1Rupee a day, which is not much to report about, shortages of food and famine-like conditions, and anywhere about $50 \%$ of the population in dire poverty, and a gigantic task national reconstruction and economic development staring in the face of a country. The economic reforms of 1991-2016 need to be understood in this historical context and the subsequent efforts at economic development [2]. Really, India's development story is very interesting as the story of development of large democratic country with so many political pulls and pressures. In India's development story it is the phase of economic reforms of liberalization of the last quarter century which is held important for the nation's take-off into the realm optimum development. For, pre-reforms period is held not to have given optimum development dividends or returns.

\section{Pre-Reforms Development}

Imaginably, the opposite of colonialism is economic nationalism or economic self-sufficient of import substitution and export promotion. The spirit of swadeshi or Indian was a part of India's about a century struggle for Independence commencing with the failed native army of British forces' rebellion in 1867. Even today, there is a strong nationalist school in the country. Mahatma Gandhi (1869-1948), the Father of the Nation, who took over the leadership of the Nation's freedom movement in 1915 after about two decades of stay and struggle in South Africa had his own plan of development for the country based integrated village development, village self-governance-panchayat raj etc. Mahatma Gandhi had envisaged a new system education called Nai Talim or New Education which combined manual work with formal education and learning some useful bread winning trade, but Gandhi's system, aft did not the requisite political 
baking Mahatma Gandhi's sagely advise is for the governments in India to keep the interests of the overwhelmingly poor of the nation upper most in their consideration.

The debate regarding the path of economic development of India post-Independence notwithstanding, under the nation's first Prime Minister, Pandit Jawaharlal Nehru (1947-64), a Fabian socialist who had an admiration for then super power USSR and its policy of heavy industrialization India had gone in for a policy of public and private sectors and planned economic development through the policy of Five Year Plans, of which the country so far had 12 plans from the First Plan in 1951-56 to twelfth 2012-2017, under the planning commission. It is unfortunate the planning commission, chaired by the Prime Minister with a Vice-Chairman, now stands abolished and is replaced by NITI Ayog, which was an unnecessary exercise.

The 1951 public sector, mixed economy, bureaucratic, high tariff and controlled economic setup was found not satisfactory in 1991 with a severe forex crisis, among other things, giving way to economic reforms of economic liberalization, which is now 25 years old. Like Rostow's stages of economic development, there seems to be different phases of economic policy or there seems to be a policy cycle, following economic down and up turns, etc.

The pre-reforms 40year period was quite momentous, marked by quite revolutionary agrarian reforms the abolition of landlordism or zamindari, land ceilings, regulation of rent (s), security of tenancy, agricultural research and extension, irrigation projects, guaranteed farm prices, food procurement, bank nationalization for agricultural credit, etc., the result of which was the Green revolution of food self-sufficiency by the early 1970s [3] [4]. There are also big steps of tractorization and other forms of mechanization like tube-wells. Still, all is not well with the prime agricultural sector, with no yield breakthrough and staring shortages in respect of in pulses, oil seeds. India is a land of marginal and small farmers and is greatly monsoon moved. For example, ample rainfall has upped the growth rate predictions from around $7 \%$ to $8 \%$. Thus, the Indian economy is greatly agriculture moved which in turn is largely monsoon moved.

The most contentious issue of the pre-reform period was industrial policy of government monopoly of some industries, semi-monopoly of some others and complete control and regulation of all private industries, according to the Industrial Policy Resolution of 1956 and the Industries (Development and Regulation) Act 1951.

In the futuristic financial sector banking and insurance also, there is the sway of the public or government sector. For example, LIC-Life Insurance Corporation of India is a byword for life insurance in the country. The Railways connecting India are a state, central government, monopoly. Whether right or wrong, India's economy had come to be termed politico-bureaucratic License Raj of high handedness. The father of economics long ago in the $18^{\text {th }}$ century England pronounced free economy to be the best of all possible economic worlds that puts people to enterprise, employment, growth and prosperity. It is a 
win-win formula.

It is growth or the rate of economic growth which is held to the talisman of underdevelopment or under-under development, poverty, unemployment, unemployment, low productivity, CAD, a 2-digit one of $10 \%$ plus, based on the experience of China since the great reforming or opening year of 1979, the ASEANs, and not the least the UAE from its founding in 1971. Of these, the UAE appears to be holistic development, which is an example for the developing world. The UAE's star-performance is to be attributed to its exceptionally exemplary political leadership. The late Stephen Covey's model of Leadership is that of Mahatma Gandhi's, which is closer to the general public, especially the poor. As said, 1991 marks a great divide in the economic history of independent India-a year of Great Reforms, U-turn, liberalization and opening of the economy.

\section{Reforms and Development}

What was the cause of India's changing horses in the midstream? India's supposedly economics idol, the USSR was a failed and falling state, its constituents aspiring to breath democratic and free economy winds. China, a stern revolutionary communist state, too had turned to a fair degree of private enterprise and foreign capital participation or investment-FDI seen as the most potent medicine for all economic ailments-and today it is in a position to challenge the USA. What of Taiwan the little or the China, Hong Kong, South Korea, the ASEAN, especially Singapore, GCC nations of which especially the UAE, which is now is concentrating on spots to prove its mettle there. The young and dynamic UAE is intent upon to be holistic or all-round state, its leadership being exceptionally visionary [5]. India appears to be suffering from a great leadership deficit. For example, the Reserve Bank of India, the country's central Bank, is among the few fine institutions of the country, but irrespective of their political persuasion every Government of India is intent on curbing the so-called "poers" of the bank to set monetary rates regarding monetary policy. Against all canons of central banking, the government of India wants to have hand in the formulation of monetary policy, which is the prerogative or responsibility of central in the interest of the general public. Ours seems to be an age of small minded politicians.

The breakdown of the Berlin Wall (1989) seemed no mean a set back to the state-run economic ideology. Thus, it is no wonder that India was found following a free-enterprise suppressive model odd economic development that does not deliver best results or good value for money being statist, bureaucratic. Free enterprise was the la mode of economic development all over, proved apt historically and also in the new age of economic development, post WW-II and the UNO, the gospel of its two development institutes the Bank-Fund is free enterprise and free trade that would take care of poverty, unemployment, humanphysical-social capital formation and low levels of living. Not that India's economic performance of 40 years between 1951 and 1991 was abysmal. It was suboptimal. 
Notwithstanding partition, flood of refugees, formidable task of rehabilitation of millions of refugees, thrust wars with Pakistan and China, big colonial baggage of feudalism and 500 'independent' big and tiny principalities to be integrated, families and food shortages and rationing, just about 100,000 ton steel production and low foreign trade base, forex scarcity, etc., the Nation with unwavering democracy and secularism had put up a good and historical show in the fields of health, education, irrigation, agriculture, science and technology, infrastructure, banking, trade and what not, which is too long to be recounted here. It was Renaissance. India's was a democratic and mixed economy model of development. The model remains still of mixed economy, the only difference brought by the 1991 Reforms is the cut down in the role of the public sector and throwing open the economy to free trade and bringing down the prohibitor import duties in some cases running to $300 \%$. There cannot be reforms without invitation to FDI.

\section{Quarter Century Reforms \& Development}

The problem of India's economic development in the first 40 years of Independence development history 1951-1991 was sub-optimal growth, hovering around 5\%, which was nicked named "Hindu" growth rate, meaning low aspirational [6] [7] [8]. According to the country's Prime Minister, Narendra Modi, India needs a sustainable growth rate of about $8 \%$ for about 30 years to overcome its multiple problems of poverty, unemployment, human capital formation, infrastructure, trade imbalances. Better still is said to be a 2-digit growth of 10 and more per cent, at which however the economy may be over heated and inflation may have a field day. As against the targeted growth rate of $8 \%-10 \%$ the targeted rate of inflation is $4 \%$. There is presently a Make in India invitation for foreign capital or FDI to boost the share of the industrial sector to about 25\% of GDP. The Rupee is made to float, and in the reform period it has lost more than 50\% its ground to the dollar, the current Rupee-Dollar exchange rate of 1:64, the rate inching towards 70 a Dollar. Still, the foreign trade equation of (X-M) evades the Indian economy. Pleasantly, it somewhat holds in the case of the UAE, but may not be any long with China hotly pursuing it. It is FDI which is held to be the talisman of India's economic deliverance or nirvana from the age-old rabid socio-economic problems of the country, from poverty to productivity.

The years 1989-91 were, especially, the years of despondence because the politics of engineered hatred and little or no economics, the result of which was precious forex reserves hitting a miserable sum of about 1.2 bn USD, sending the alarms of debt default. There was airlift of $47 \mathrm{t}$ gold to Bank of England for $\$ 400$ $m$ [9]. Enough of a new government (Congress) with weak parliament numbers under P.V. Narsimha Rao, a homespun person from the humble state of Telangana, with Oxford economist Dr. Manmohan Singh as Finance Minister, on 25 July 1991, had cutting the role of public sector to essential or unavoidable industries like defense, atomic energy and 20\% Rupees devaluation and free trade. Nothing short of an economic revolution, this is still on. 


\section{Conclusion}

The result a $\$ 2.08$ trillion economy today, steady in the global financial crisis of $2008,>7 \%$ growth rate which may hit a steady $8 \%-9 \%, \$ 366$ bn forex reserves, $\$ 44$ bn FDI inflows and also some outflows, 1 billion plus mobile subscribers, poverty down to $20 \%$, a booming through (-) still, to trade sector, with IT exports some 100,000 registered companies, $400 \mathrm{~m}$ Middle Class, a booming service sector. In short, India is now a global economic power to reckon with. This is due to all 24/7/365 external and internal communication. Still, there are miles and miles to go in terms of physical fitness as brought home by the Olympics, sex ratio and Law and order, infrastructure, public health, education standard, green environment and so on.

\section{References}

[1] World Bank (2015) World Development Indicators Database. World Bank, Washington, DC.

[2] Kumar, R. (2016) Making Reforms Work for the Common People. Economic \& Political Weekly, 51, 51-55.

[3] Ahluwalia, I.J. (1985) Industrial Growth in India: Stagnation since the Mid-Sixties. Oxford University Press, Delhi.

[4] Bhagwati, J. and Desai, P. (1970) India: Planning for Industrialization, Industrialization and Trade Policies since 1951. Oxford University Press, Delhi.

[5] Amponsah, C. and Ahmed, G. (2017) Factors Affecting Entrepreneurships in Emerging Economies: A Case of Dubai. Journal of International Business and Entrepreneurship Development, 10, 120-137. https://doi.org/10.1504/JIBED.2017.084302

[6] Ahluwalia, M.S. (2016) The 1991 Reforms: How Home-Grown Were They? Economic \& Political Weekly, 51, 39-46.

[7] Rodrik, D. and Subramanian, A. (2004) From Hindu Growth to Productivity Surge: The Mystery of the Indian Growth Transition. IMF Working Paper No WP/04/77, May, Washington DC.

[8] Panagariya, A. (2004) India in the 1980s and 1990s: A Triumph of Reforms. IMF Working Paper No WP/04/43, March, International Monetary Fund, Washington DC.

[9] Rakshit, M. (2004) Some Macro Economics of India's Reforms Experience. In: Basu, K., Ed., India's Emerging Economy: Performance and Prospects in the $1990 \mathrm{~s}$ and Beyond, MIT Press, Cambridge, MA, 108. 
Submit or recommend next manuscript to SCIRP and we will provide best service for you:

Accepting pre-submission inquiries through Email, Facebook, LinkedIn, Twitter, etc. A wide selection of journals (inclusive of 9 subjects, more than 200 journals)

Providing 24-hour high-quality service

User-friendly online submission system

Fair and swift peer-review system

Efficient typesetting and proofreading procedure

Display of the result of downloads and visits, as well as the number of cited articles Maximum dissemination of your research work

Submit your manuscript at: http://papersubmission.scirp.org/

Or contact tel@scirp.org 